\title{
POLITIK PENDIDIKAN ISLAM MASA MODERN; MEMBACA GAGASAN TOKOH PEMBAHARU DI NEGARA TURKI, INDIA, DAN MESIR
}

\author{
Zainur Arifin \\ Institut Agama Islam Bani Fattah Jombang, Indonesia \\ E-mail: zainur.arifin@gmail.com
}

\begin{abstract}
In the middle of the fight and friction of ideas in the early 20th century Mustafa Kemal emerged a prominent Turkish Nationalists and the new leader who managed to expel Greece from Turkey. Furthermore, thanks to the leadership talent and brilliance of his political ideas, he managed to be proclaimed Turkish Republic and he was elected as a President of the first by the Grand National Assembly. Ahmad Khan in India got a traditional upbringing in religious education. His formal education ended when he was 18 years old. His political activities is the struggle to defend the Muslims of British accusations after the uprising of 1857. By convincing the British that Islam does not play a major role in the uprising, but due to British intervention in the matter of religion. Taha Husein one reformer in the Egyptian thinker who saw the need for Egypt to learn from Europe as well take the culture if Egypt wants advanced and powerful. This idea was initially considered controversial and have not been received at the time of Egyptian society, including intellectuals. As well regarded as the idea of secularization that have come out of Islam.
\end{abstract}

Keywords: Political Islamic Education, Ideas Reformer, Turki India and Mesir 


\section{Kemal Attaruk dan Pembaharuannya}

Usaha pembaharuan di Kerajaan Turki Usmani pada periode modern dipelopori oleh Sultan Mahmud II (1785-1839). Politik will dan demokratisasi yang datang dari Sultan yang berjiwa pembaharu ini mendorong perkembangan pemikiran modern di Kerajaan Turki Usmani ini yang ditandai oleh tampilnya putra putri Turki yang berpendidikan Barat modern memunculkan ide-ide baru. Seperti golongan Tanzimat, golongan Usmani muda, golongan Nasionalisme Turki, golongan Islamisme dan golongan Westernisme. Sekalipun ide-ide dasar yang menjiwai pemikiran pembaharuan mereka mempunya corak dan orientasi yang berbeda namun tujuan mereka sama untuk mewujudkan Turki menjadi negara maju dan modern.

Sementara itu, ditengah-tengah pertarungan dan pergesekan ide-ide diantara golongan-golongan pembaharu itu, pemerintah Turki yang didominasi Turki muda melibatkan diri dalam percaturan politik negara Eropa yang menimbulkan pecahnya perang dunia I. Dalam perang ini, Turki berpihak kepada Jerman, Jerman kalah. Akibatnya kekuatan politik dan tentara Turki berantakan. Tentara sukutu berhasil menduduki Istambul. Situasi ini dimanfaatkan pula oleh Yunani menyerbu Turki dari Izmir dibawah perlindungan kapal perang sekutu.

Dalam Kondisi demikian tampil Mustafa Kemal, tokoh Nasionalis dan pemimpin baru Turki menyelamatkan Turki dari kehancuran dan dari ancaman negara-negara Barat. Ia berhasil mengusir Yunani dari Turki. Keberhasilan ini menempatkannya menjadi tokoh Nasionalis yang berpengaruh dalam barisan kaum Nasionalis Turki. Selanjutnya, berkat bakat kepemimpinan dan kecemerlangan ide-ide politiknya, ia berhasil memproklamirkan Turki menjadi Negara Republik dan ia dipilih sebagi Presiden pertama oleh Majelis Nasional Agung. Jabatan ini ia pegang dari tanggal 29 Oktober - 10 November 1938.

Mustafa Kemal melakukan perubahan yang cukup mendasar dan tindakan berani, yaitu menghapuskan jabatan Sultan lalu menghapuskan jabatan Khalifah dari Turki. Tindakan ini diperkuat konstitusi republik. Akhirnya Turki menjadi Negara Republik Sekuler murni setelah prinsip sekulerisme masuk pada konstitusi pada tahun 1937. Keberhasilan gerakan Kemal ini dapat dikatakan sebagai puncak dari usaha pembaharuam di Turki. Jelasnya, Mustafa Kemal dapat dikatakan sebagai "gong" perjuangan pembaharuan di Turki. 


\section{Pembaharuan Kemal Attaturk}

Usaha pembaharuan kemal dimulai ketika perjuangan kemerdekaan telah selesai. Dalam langkah pembaharuannya tersebut ia melihat Barat sebagai model yang ideal, karenanya ia ingin mewujudkan peradaban Barat di Turki dengan jalan melakukan westernisasi dan skularisasi hampir di segala bidang. Hal ini dilakukan karena Kemal melihat Barat telah mencapai kemajuan di segala bidang sedangkan dunia Islam, khususnya Turki yang kekuasaannya begitu luas sedang tenggelam dalam kemunduran dan telah mulai surut pengaruhnya. Selain itu, Eropa Barat juga mulai mengembangkan program militerisasi guna memperkuat negerinya masing-masing, Starrett sebagaimana dikutip Robert W. Hefner mengatakan "Ottoman power had begun to decline, and gov ernment officials began to appreciate that Western Europe had developed a military and technological edge over its long-time rival. ${ }^{1}$

Sultan Salim III (1789-1807) sebagai penguasa Usmani saat itu melihat kemajuan Eropa sebagai sesuatu yang mempesona karena Eropa Barat yang kalah dalam Perang Salib melawan Islam dalam waktu yang singkat telah membangun negerinya secara pesat.

Karena itulah kemal mengambil peradaban Barat sebagai contoh yang ideal. Bahkan seperti disebutkan Harun Nasution, peradaban Barat yang diambil tidak setengah-setengah, tetapi secara keseluruhannya. Ia berpendapat bahwa Turki dapat maju hanya dengan meniru Barat. Setelah kemerdekaan selesai harus mulai mewujudkan paradaban Barat di Turki. Masyarakat Turki harus menjadi masyarakat yang mempunyai peradaban Barat.

Realisasi dari perwujudan peradaban Barat di Turki tersebut dilaksanakan berdasar tiga konsep dasar yang juga merupakan program Kemal dalam melakukan pembaharuannya : westernisasi, akularisasi dan nasionalisme. Ketiga pemikiran inilah yang dijadikannya acuan dalam pembaharuannya dalam bidang politik, hukum, pendidikan, kebudayaan dan ekonomi.

Pertama, dibidang politik. Sebagai realisasi dari prinsip dasar pemikarannya, Kemal membentuk suatu negara baru yang disebut negara republik dan ibu kotanya Ankara. Ia sendiri yang ditunjuk sebagai Presiden dan Ismet sebagai Perdana Mentri. Kemudian ia membentuk Majelis Nasional Agung dan dalam sidang perdananya ditetapkan beberapa keputusan sebagai berikut; (a) kekuasaan tertinggi terletak di tangan rakyat Turki; (b) majelis Nasional Agung merupakan perwakilan

\footnotetext{
${ }^{1}$ Starrett, dalam Hefner, Robert. n Zaman Qasim, Schooling Muslim (1998), 26-30
} 
rakyat tertinggi; (c) majelis Nasional Agung bertugas sebagai badan legislatif dan badan eksekutif; (d) majelis nagara yang anggotanya dipilih dari Majelis Nasional Agung akan menjalankan tugas pemerintah; an (e) ketua Majelis Nasional Agung merangkap jabatan Ketua Majelis Negara.

Keputusan-keputusan tersebut di atas memberikan gambaran bahwa konsultasi yang dimajukan kemal merupakan bentuk baru dan berbeda dengan pemikiran elite birokrat tradisional yang kedaulatannya terletak di tangan Sultan dan Khalifah.

Alexander $\mathrm{H}$. de grot memandang bentuk negara baru itu sebagai negara republik yang berdasarkan nasionalisme Turki. Pendapat ini sesuai dengan pernyataan Harun Nasution bahwa ide nasionalisme yang dimajukan Kemal sangat terbatas daerah geografinya. Di dalam Piagam Nasional tahun 1920 disebutkan antara lain bahwa Turki melepaskan tuntutan teritorial terhadap daerah-daerah yang dahulu terletak di bawah kekuasaan kerajaan Usmani, kecuali daerah yang didalamnya terdapat mayoritas Turki. Di dalam salah satu pidatonya, ia menjelaskan bahwa kaum nasionalis akan berkerja dalam lingkungan daerah territorial Turki untuk kebahagiaan dan kesejahteraan rakyatTurki. Dengan demikian, tidaklah salah kalau Stoodard mengatakan bahwa tujuan bangsa Turki dengan nasionalismenya adalah menTurkikan segala-galanya agar menjadi bangsa Turki yang berbahasa satu, berbudaya satu dan dijiwai oleh semangat patriotik Turki.

Semenjak terbentuknya negara republik inilah Kemal mengambil alih semua jabatan-jabatan strategis dan membebaskan pengaruh-pengaruh agama di dalamnya. Namun, sebagai yang telah dijelaskan bahwa kemal tidak sampai menghilangkan agama. Negara masih memainkan peran kunci dalam kontrol agama melalui Diektorat Jendral Urusan Keagamaan, suatu lembaga yang ada di bawah wewenang Perdana Mentri. Jadi benar apa yang dikatakan Harun Nasution bahwa negara yang baru lahir ini belumlah negara sekuler, sebagai yang terkandung dalam konstitusi 1921 bahwa Turki adalah negara republik dan agama negara adalah Islam. Adapun bentuk negara yang sekuler adalah merupakan perkembangan yang selanjutnya.

Setelah Negara republik terbentuk, di Turki terdapat dualisme dalam memegang kekuasaan duniawi, yaitu Raja Turki di satu pihak dan Majelis Negara di pihak lain, untuk menghindarkan Turki dari dualisme pemerintahan ini, langkah pertama yang di tempuh Kemal adalah menghapuskan lembaga kesultanan pada bulan November 1992. Selain itu, ada tendensi lain dalam penghapusan jabatan sultan ini, yaitu karena sultan di Istambul masih di anggap oleh sekutu sebagai penguasa satu- 
satunya, padahal sultan itu sudah tidak berkuasa lagi. Dengan dihapuskannya jabatan sultan itu, sudah barang tentu semua instansi yang berda di bawah kekuasaannya kehilangan fingsi strukturalnya, salah satu diantaranya adalah Syekh al-Islam. Biro ini dihapuskan pada tahun 1924 M. Dan kemudian diganti dengan kementrian syariat yang langsung bertanggung jawab kepada Presiden. Sebagai dikatakan Harun Nasution Kementrian ini di zaman Kerajaan Usmani tidak ada. Jadi, jelaslah bahwa Turki diperintah oleh seorang Presiden dengan sebuah konstitusi. Salah satu pasal dari kon stitusi itu adalah: Kedaulatan berada di tangan bangsa tanpa syarat. Kekuasaan Legislatif dijalankan oleh wakil-wakil dalam sidang Majelis Nasional Agung. Pemerintahan didasarkan atas pemerintahan rakyat yang langsung menentukan nasib mereka sendiri.

Dengan demikian, Turki akan terhindar dari kekuasaan dan system pemerintahan yang absolute. Setelah jabatan sultan dihapuskan, masih ada lagi satu jabatan lain yaitu jabatan Khalifah yang pada waktu itu dipegang oleh abd al-Majid. Namun Khalifah tidak mempunyai kekuasaan duniawi, yang ada hanyalah kekuasaan spritural. Oleh karena itu, di Turki tidak lagi terjadi dualisme dalam pemegang kekuasaan duniawi. Sungguhpun demikian, dalam kenyataannya kedudukan kahalifah masih diberi pengertian oleh golongan Islam sebagai kepala Negara. Mereka mempertahankan adanya Khalifah dan memperkuat kedudukannya, sehingga ia tetap bertindak sebagai Raja Usmani sebelumnya, menerima wakil-wakil ke luar negeri, mengadakan prosesi kebesaran pada hari Jum'at ke masjid untuk sembahyang dan tetap tinggal di istana Istanbul.

Mengenal eksistensi lembaga kekhalifahan di Turki memang terjadi suatu perdebatan sengit antara dua golongan yang masing-masing mempertahankan prinsipnya, yaitu golongan Islam dan golongan Nasionalis. Akan tetapi, akhirnya pada tahun 1924 jabatan khalifah yang merupakan penguasa spiritual dan politik tertinggi yang berkuasa selama berabad-abad di kesultanan Turki dihapus oleh Kemal. Kemudian Khalifah Abd. al-Majid diperintahkan meninggalkan Turki, dan ia bersama keluarganya pergi ke Swiss.

Sebagai reaksi terhadap penghapusan kedua jabatan tersebut, muncul golongan oposisi yang diatur oleh kelompok mistik dan kelompok agama yang diorganisasikan menurut garis-garis tarekat. Mereka melakukan kegiatan bawah tanah untuk melawan Kemal. Kelompok mistik di antaranya ialah Bektasiah, Naqsabandiah, Qadariah dan Maulawiyah.

Oleh karena itu, pada tahun 1925 aliran-aliran keagamaan dan tarekattarekat dibubarkan, begitu juga tempat-tempat pertemuan mereka, tekke 
dan makam-makam ditutup. Kelihatannya hal ini merupakan jalan yang terbaik bagi Kemal karena kelompok-kelompok mistik itu dipandang sebagai penghalang terhadap langkah-langkah kelompok nasionalis.

Kedua, Bidang Hukum dan Pendidikan. Sebagai kelanjutan dari usaha sekularisasinya, Kemal menghapuskan kementrian urusan syari'at yang semula dibentuk sebagai pengganti Biro Syaikh al-Islam. Kemudian pada tahun 1926 hukum syari'at diganti oleh Undang-Undang Sipil yang diambil dari Undang-Undang Swis. Perkawinan bukan lagi dilakukan menurut syari'at tetapi menurut Hukum Sipil. Selanjutnya dibuat hukum baru seperti Hukum Dagang, Hukum Pidana, Hukum Laut dan Hukum Obligasi yang semuanya diambil dari hukum Barat. Dihapuskannya kementrian syari'at ini menurut Serif Mardin bertujuan untuk mempermudah usaha untuk menghilangkan artikel-artikel dari konstitusi 1921 yang menyatakan Islam sebagai agama negara. Setelah itu, sembilan tahun kemudian ia memasukkan prinsip sekularisme ke dalam konstitusi secara resmi menjadi negara sekuler. Selain itu, bidang pendidikan pun mengalami pembaharuan yang sama oleh Kemal yaitu mengalami proses sekularisasi.

Langkah-langkah pembaharuan dalam bidang pendidikan adalah tanggal 7 Pebruari 1924 dikeluarkan dekrit yang melepaskan semua unsur keagamaan dari sekolah-sekolah asing. Sebulan kemudian, tanggal 1 Maret 1924 diterima ide penyatuan pendidikan di bawah 'satu atap' yang berada di bawah kementrian pendidikan yang berarti penghapusan semua bentuk pengawasan yang dilakukan oleh badan-badan Islam terhadap sekolah-sekolah. Simbol-simbol yang menjadi kebudayaan Islam seperti bahasa Arab dan bahasa Persia yang terdapat dalam kurikulum sebelumnya, pada tahun 1928 dihapuskan dan tulisan Arab tersebut digantikan dengan tulisan Latin. Pada tahun 1930 dan 1933, pendidikan agama ditiadakan di sekolah-sekolah yang berada di sekolah-sekolah yang berada di wilayah perkotaan maupun pedesaan. Pendidikan agama dialihkan menjadi tanggung jawab orang tua dan lembaga pendidikan imam dan khatib pada tahun 1931. Dua tahun berikutnya Fakultas Teologi di Istambul juga ditutup. Dari uraian di atas bisa dilihat bahwa Kemal hanya mengikis habis unsur-unsur agama yang terdapat pada konstitusi atau struktur pemerintahan. Ia tidak menghilangkan agama sama sekali dari kehidupan rakyat Turki.

Dengan pengalihan bahwa pendidikan agama menjadi tanggung jawab orang tua. Kemal tidak bermaksud menghilangkan agama. Apalagi seperti dikatakan Syafici Anwar, bahwa Kemal dalam pembentukan negara modern lebih mengutamakan negara daripada agama adalah suatu 
konsep yang diilhami oleh Emile Durkheim. Seperti Durkheim, Kemal percaya bahwa negara modern dapat dipegang oleh 'agama rakyat', yang di Turki agama rakyat tersebut adalah Islam.

\section{a. Bidang Peradaban dan Ekonomi}

Westernisasi dan sekularisasi juga dilakukan dalam bidang peradaban dan ekonomi. Dalam peradaban, pada tahun 1925 pemakaian terbus dilarang dan diganti dengan topi Barat. Pakaian agama juga dilarang dan rakyat Turki harus mengenakan pakaian Barat, baik pria maupun wanita. Pada tahun 1931 dibuat keputusan bahwa azan harus dengan bahasa Turki, bukan bahasa Arab. Al-Qur'an harus diterjemahkan ke dalam bahasa Turki agar dapat dipahami oleh rakyat Turki. Khutbah Jum'at juga harus diberikan dalam bahasa Turki. Pada tahun 1935 dikeluarkan pula Undang-Undang yang mewajibkan warga negara Turki mempunyai nama belakang. Hari cuti resmi mingguan dirubah dari hari Jum'at menjadi hari Minggu. Corak musik yang beraliran timur harus diganti dengan musik yang beraliran Barat. Dan radio Turki harus menyiarkan lagu-lagu Barat.

Dari perubahan di atas dapat dimengerti bahwa yang diinginkan oleh Kemal adalah Islam yang di-Turki-kan dan tidak terikat oleh peradaban Timur (Arab). Peradaban Timur nampaknya dipandang oleh Kemal bukan Islam. Baginya Islam adalah agama rasional yang dapat diperlukan bagi umat manusia dan ajarannya harus dipahami oleh rakyat Turki dengan tidak harus terbelenggu oleh tradisi ketimuran (kearaban). Dengan demikian, dapatlah dikatakan bahwa Islam sebagai pedoman hidup rakyat Turki secara personal dan peradaban Barat sebagai acuannya. Meskipun Turki banyak menyerap peradaban Barat, akan tetapi Kemal membatasi diri untuk bekerjasama dengan Barat dalam bidang ekonomi. Ia tidak menginginkan negaranya dikuasai oleh kekuatan asing seperti yang pernah dialami oleh pemerintahan Sultan. Sumber-sumber vital dalam negeri diambil alih oleh negara. Untuk mengantisipasi resesi ekonomi dunia sebagai akibat Perang Dunia I, pihak penguasa Turki menerapkan beberapa kebijaksanaan ekonomi, antara lain mengurangi volume perdagangan luar negeri, menekan belanja rutin, mengurangi pengeluaran atau anggaran militer menjadi rata-rata 28 $\%$ dari seluruh anggaran pengeluaran, memberi bantuan kepada sektor swasta agar bisa lebih mandiri.

Perbaikan-perbaikan di bidang ekonomi ini memang sangat menentukan bagi kelanjutan gerakan pembaharuan Kemal, karena kalau tidak ada pembaharuan dalam bidang ini gerakan oposisi akan lebih mudah dalam mengacaukan situasi. 
Sebagai akibat dari kebijaksanaannya, ekonomi Turki pada tahun 1949 sangat baik. Di sektor pertanian masyarakat Turki selalu mengalami surplus, sehingga kebutuhan pangan dalam negeri selalu terpenuhi. Dengan demikian, Kemal dapat mempertahankan kekuasaannya selama 15 tahun sekalipun banyak tantangan dari pihak oposisi.

Dalam paparan diatas dapat dikemukakan beberapa kesimpulan, sebagai berikut; (a) Kemal adalah tokoh pembaharu Tukri, berkuasa selama 15 tahun. Dialah bapak pendiri Turki Modern yang digelari attaturk, yang ingin memajukan Turki dengan meniru Barat sebagai model yang ideal. Hal ini disebabkan kemajuan Barat yang pesat di segala bidang, baik militer maupun ilmu pengetahuan dan teknologi; (b) dalam mewujudkan cita-citanya, ia melakukan gerakan pembaharuan yang dibangun atas dasar sekularisasi, westernisasi dan nasionalisme. Dengan kata lain, untuk memajukan Turki harus dengan mentransformasi apaapa yang terdapat di Barat ke dalam negerinya. Dengan demikian Turki akan maju dan modern; (c) dari upaya reformasi ini, Kemal mendapat tantangan yang cukup besar dari berbagai kalangan, terutama kalangan 'ulama tradisional'. Akan tetapi, ia tampaknya yakin bahwa ia tidaklah ingin menghapuskan Islam secara mendasar. Ia lebih memahami Islam secara rasional dan realistis; dan (d) Kemal mengetahui akan perlunya perubahan dan pembangunan dalam bidang ekonomi rakyat, di samping mempunyai implikasi terhadap kesejahteraan rakyat, juga berdampak politis.

Pemikiran dan gerakan pembaharuan yang dilakukan oleh Kemal, disamping telah membuahkan hasil yang sangat menggembirakan, ialah menyadarkan umat Islam di Turki dari ketertinggalannya dalam bidang ilmu pengetahuan dan teknologi, dari Barat, oleh karena itu Kemal memberikan pencerahan kepada umat Islam di Turki khususnya, umat Islam di seluruh dunia pada umumnya, karena keadaan umat Islam memang serba tertinggal, bahkan tertinggal jauh.

Dalam gerakan peemikiran dan pemabaharuan yang dilakukan oleh Kemal, bukanlah sebuah jalan tol yang licin dan bukan pula jembatan emas yang terbebas dari onak dan duri, serta bukan pula lautan yang lepas bebas tanpa gelombang yang besar dan dahsyat, atau jembatan emas yang dengan mudah dapat dilalui oleh setiap manusia yang akan menyebrang, tetapi sebuah perjalanan panjang yang sangat melelahkan, serta membutuhkan kerja keras dan kesungguhan yang membutuhkan kelapangan pada, serta kerendahan Hali, dan pengorbanan perasaan yang mendalam, serta ketenagan jiwa dan keterbukaan dalam menghadai setiap persoalan yang datang mengahadang, silih berganti, adakala susah yang 
tak berujung dan rintangan yang terus menerus malang melintang, kesulitan yang talc putus-putus membelit setiap pembaharu serta pelaku perjuangan baik di medan perang maupun di medan pergumulan kehidupan sehari-hari.

Pembaharuan yang dilakukan Kemal, mengadakan kontak Islam dengan Barat, mendorong kaum muslimin berpikir kritis, analitis, obyektif dan rasional, maka Turki menjadi berubah dari kegelapan menjadi terang benderang, meninggalkan kebodohan dan kejumudan, dikuburkannya dalam dalam taklid dan mengikuti sesuatu yang tak berdasar, beralih menjadi muttabi' al-muttabi' yang taat dan memegang teguh ajaran Islam yang menyejukan seerta mendorong kepada kemajuan, menyadarkan jiwa yang tertekan, membuka mata yang buta.

Yang tak kalah pentingnya adalah karena jasa jasa kedua orang tua Kemal. Khususnya jasa ibundanya yang telah mengantarkan Kemal menjadi manusia yang berguna bagi bangsanya, karena pengarahan pendidikannya kedua orang tuanyalah yang telah mengadakan Kemal sebagai seorang yang memiliki kemampuan ilmu dan kemampuan berpikir maju, diaertai semangat perjuangan yang sangat luar bisaa.

Pendidikan militer yang ditempuh Kemal, dengan meraih jabatan Kapten. inilah yang telah menjadikan Kemal sebagai militer yang memiliki kemampuan prima, dan bahkan menyandang milter profesional, kemampuan mengatur taktik dan strategi perang, darah kemiliteran yang mengalir dalam tubuhnya, telah mendorong Kemal tetap berjuang, serta berpikir maju, dalam berbagai bidang, termasuk datum bidang ekonomi yang memberikan kesejahteraan kepada bangsanya. ${ }^{2}$

\section{Sayyid Ahmad Khan dan Pembaharuannya (1817-1898)}

Sekurang-kurangnya ada dua kejadian penting pada abad ke-18 yang turut mewarnai suasana kaum Muslimin India secara politis seputar abad ke-19 M. Pertama, merosotnya kekuasaan kerajaan Mughal yang diawali dengan wafatnya Aurangzeb pada 1707 M. Kedua, seiring dengan itu, kekuasaan dan kedudukan para pedagang Inggris di India pun semakin kokoh.

Dengan meninggalnya Aurangzeb, para gubernur di berbagai propinsi melespaskan diri dari kekuasaan kerajaan Mughal, sehingga pada gilirannya wilayah kekuasaan kerajaan ini hanya meliputi wilayah Delhi dan sekitarnya saja.

\footnotetext{
${ }^{2}$ Mahmud Syafe'i, Perkembangan Modern Dunia Islam (t.tp.; CV. Vasindo dan Value Press Bandang, 2008)
} 
Perpecahan politik dalam pemerintahan ini menimbulkan kekacauan. Kekacauan ini dimanfaatkan oleh kaum Maratha untuk menyusun kekuatan di Daccan. Kelompok ini adalah orang-orang Hindu Militan di propinsi Bombay. Dengan memanfaatkan kekacauan dan kelemahan kerajaan Mughal mereka berhasil memperluas wilayah kekuasaannya sehingga menjadi kerajaan yang kuat di daerah Daccan sekitar tahun 1737 M.

Dalam suasana instabilitas politik itu, orang-orang Inggris mengambil kesempatan untuk memperkokoh kedudukannya sebagai pedagang dan berusaha merebut posisi politik. Usaha mereka ini berhasil dengan jatuhnya Benggala ke tangan mereka dalam pertempuran Plassey pada $1757 \mathrm{M}$.

Sisa-sisa kekuatan Mughal akhirnya habis setelah terjadi suatu pemberontakan pada tahun 1857 M. Peristiwa ini merupakan babak terakhir keruntuhan politis seluruh kaum Muslimin di anak benua India.

Namun demikian dalam periode keruntuhan politik kaum Muslimin itu, masih muncul beberapa tokoh pemikir dikalangan umat Islam India. Salah seorang tokoh yang akan kita diskusikan ialah Sayyid Ahmad Khan. 1. Biografi Sayyid Ahmad Khan

Sayyid Ahmad Khan lahir pada 17 Oktober 1817 M di Delhi dan meninggal dunia pada 27 Maret $1898 \mathrm{M}$, dalam usia 81 tahun. Ayahnya, Mir Muttaqi, seorang pertapa salih, yang sangat besar pengaruhnya di istana kaisar, Mughal Akbar Shah II. Setelah mengundurkan diri dari jabatannya, ia menghabiskan hampir seluruh waktunya bersama Ghulam Ali, seorang suci Mujaddid pada saat itu. Ahmad Khan muda menjadi orang yang salih karena ajaran Shah Ghulam Ali. Ahmad Khan belaar ilmu kenegaraan dan diperkenalkan pada kebudayaan Barat oleh kakeknya dari pihak ibu, Khawaja Fariduddin, yan selama delapan tahun menjadi Perdana Menteri pada kaisar Mughal Akbar II.

Dari garis bapaknya, Ahmad Khan keturunan langsung dari Nabi Muhammad SAW melalui Husin ra. Oleh karena itu ia boleh memakai gelar sayyid.

Ahmad Khan mendapat didikan tradisional dalam pendidikan agama dimulai dari membaca alquran. Setelah itu ia melanjutkan studinya ke maktab. Disini ia belajar bahasa Persia, arab dan matematika, disamping itu geometri dan ilmu kedokteran juga di pelajarinya. Pendidikan formalnya berakhir ketika ia berusia 18 tahun. Peristiwa kematian ayahnya pada $1838 \mathrm{M}$ membawa perubahan besar dalam hidupnya. Kenyataan ini berdampak sikologis dan finansial 
terhadap keluarganya. Karena ia memutuskan untuk bekerja pada serikat India timur meskipun keluarganya tidak menyetujuinya, karena di antara mereka masih ada perasaan anti-Inggris. Kemudian ia bekerja sebagai hakim. Tahun 1846 ia kembali ke delhi untuk melanjutkan pendidikannya.

Kegiatan politik ahmad khan yang cukup berarti ialah perjuangannya membela golongan Islam dari tuduhan Inggris setelah peristiwa pemberontakan 1857. Ia juga berusaha mencegah terjadinya kekerasan dengan penuh resiko menolong banyak orang Inggris dari usaha pembantaian dan pembunuhan pada saat itu yang di pimpin oleh nawab Mahmud khan pemimpin pemberontakan anti Inggris. Di samping itu ia berusaha meyakinkan pihak Inggris, bahwa golongan Islam tidak memegang peranan utama dalam pemberontakan itu. Ia menjelaskan, bahwa sebenarnya itu disebabkan antara lain karena intervensi Inggris dalam soal agama, seperti pendidikan agama Kristen yang diadakan di panti-panti asuhan yang dikelola oleh orang Inggris dan pembenukan sekolah-sekolah missi. Selain itu menurutnya, bahwa tidak adanya wakil-wakil golongan Islam dan hindu dalam lembagalembaga perwakilan, rakyat India tidak mengerti tujuan Inggris. Rakyat menyangka Inggris akan mengubah agama mereka menjadi Kristen. Sebaliknya Inggrispun tidak mengerti keinginan rakyat India. Dan dengan demikian tidak terjalin tali persahabatan antara Inggris dengan rakyat India. Atas jasa-jasanya pada waktu terjadi revolusi, pemerintahan Inggris bermaksud memberinya hadiah sebidang tanah hasil sitaan dari orang islam, tetapi ia menolak pemberian itu kecuali gelar sir.

Selama dan pasca terjadinya pemberontakan umat Islam selalu dicurigai bahkan semua bencana dan kerusuhan yang terjadi dialamatkan kepada orang Islam. Ahmad khan tampil dengan segala resiko kemampuan rehabilitasi nama baik umat Islam diantara orang Inggris dan menyatakan perbuatan makar yang dilakukan umat Islam dicap sebagai perbuatan kriminal dan sangat tidak adil kesalahan itu dialamatkan kepada seluruh umat Islam.

Ahmad Khan dengan segala upaya mendamaikan umat Islam dengan pemerintahan Inggris. Ia mengajak masyarakat umat Islam India agar tetap loyal terhadap pemerintah Inggris. Kepada umat Islam ditegaskannya bahwa persahabatan antara mereka dengan pihak Kristen diperkenankan oleh agama bahkan ia menyerang kelompok ortodoks dengan menyatakan dalam suatu pamphlet bahwa orang muslim makan bersama orang Kristen dan Yahudi adalah tidak 
dilarang. dalam usahanya menetralisasi politik perbudakan dengan Islam, Sayyid khan mengutip contoh Nabi Yusuf yang telah mengabdikan dirinya terhadap fir'aun di Mesir, beliau loyal kepadanya dan patuh meskipun diketahui fir'aun itu bukan seorang muslim. ${ }^{3}$ Usaha-usaha ahmad khan itu tampaknya membawa hasil yang baik bagi kedua bela pihak. Pada akhirnya abad ke-19 sudah menjadi kebisaaan orang-orang Islam makan bersama orang-orang Inggris. Sejak saat iu orang Islam bertambah keinginannya untuk belajar pada orang Barat, dan kecurigaan orang Inggris terhadap mereka menjadi berkurang. Dan akhirnya orang Islam memiliki lembaga perguruan tinggi model Barat.

2. Ide-ide Pembaharuan Sayyid Ahmad Khan

Modernisme Islam merupakan sebuah respon Muslim modern dalam rangka menghadapi Barat di abad 19 dan 20 M. perhatian utama difokuskan untuk memurnikan ajaran Islam dari elemenelemen yang tidak Islami atau Bid'ah, menginterpretasikan beberapa aspek sosial kemasyarakatan dan menyesuaikannya dengan unsur-unsur modern dan perkembangan zaman. Sehingga umat Islam dapat merespon perubahan masa dan dapat berpartisipasi aktif menyumbangkan pemikiran-pemikirannya untuk perkembangan dunia modern dalam jangka waktu yang panjang serta untuk membuktikan kebenaran agamanya.

Sebagai seorang Muslim modernis, Ahmad Khan juga bertujuan untuk memurnikan Islam dan menyesuaikannya dengan konteks masyarakat modern; dengan cara mengadakan penafsiran ulang terhadap ajaran-ajaran Islam, mengadopsi sains dan teknologi Barat serta membentuk organisasi-organisasi untuk memperbaiki kondisikondisi sosial masyarakat tanpa meninggalkan pesan moral dan nilainilai Islami.

a. Pemikiran Keagamaan

1) Sebelum tahun 1857

Pada tahap pertama pemikiran Ahmad Khan ketika menetap di Delhi 1817-1857, ia merupakan sosok muslim tradisionalis. Pemikiran keagamaannya apabila dilihat pada tema-tema tulisannya sangat bercorak puritan, sektarian dan apologetic. Meskipun demikian sejak permulaan abad ke-19, umat Islam India telah melakukan kontak dengan Inggris, pemikiran

3 Jameelah, Maryam and Margaret Marcus, Islam dan Modernisme (Surabaya: Usaha Nasional, t.th.), 79 
keIslaman Ahmad Khan selama periode ini belum terpengaruh dengan suasana yang mengitarinya. Sumber inspirasi pemikirannya ialah gerakan pembaharuan keagamaan yang dipelopori oleh Shah Waliyullah dan gerakan Wahabi.

Pemikiran keagamaannya selama periode ini secara luas terefleksi dalam tulisannya sebelum tahun 1857, seperti dalam buku Jilaul Qulub bi Zik al-Mahbub (menyucikan hati dengan mengingat yang dicintai). Buku ini ditulis pada tahun 1848, merupakan sebuah buklet kecil yang berisi tentang cerita kelahiran, wafat, wahyu dan peristiwa-peristiwa lain dalam sisi kehidupan akurat untuk memperingati upacara maulid Nabi besar Muhammad SAW.

Disamping itu ada dua buah karya besar lainnya masingmasing dalam bidang karya sastra dan sejarah. Karya sastranya yang pertama dan terbesar adalah pujian kepada kota Delhi Asaru Al-Sanadid peninggalan-peninggalan lama dari Delhi yang diterbitkan pada 1847'. Uraian dalam buku ini mengisahkan tentang gedung-gedung utama di dalam sekitar kota Delhi. Dalam uraiannya dijelaskan pula tentang para tokoh terkenal yang mendiami kota ini sampai pada kurunnya. Sedangkan bukunya yang kedua merupakan hasil suntingan karya Abul Fazal yang berisi tentang Sejarah Pemerintahan Islam di India yang berjudul Aini Akbari.

Melihat kepada hasil karyanya tersebut, pemikiran keagamaan Ahmad Khan sudah mulai kritis terhadap praktekpraktek keagamaan dalam masyarakat. Hal ini karena pola pikirnya banyak dipengaruhi oleh Shah Waliullah dan Wahabi.

2) Setelah Tahun 1857

Setelah revolusi 1857, Ahmad Khan benar-benar menjalin kerjasama dengan pihak Inggris. Sebagai hasil hubungan baik itu ia diberi kesempatan mengadakan lawatan ke Inggris. Setibanya di sana ia melihat kemunduran bangsanya yang sangat mencolok dibandingkan kemajuan yang ia lihat.

Peristiwa 1857 dan perjalanannya ke Inggris itu memberikan suatu nuansa baru terhadap pemikirannya. Peristiwa ini tidak hanya berdampak sosial politik, tetapi jua membawa implikasi kepada agama dan pola pikirnya pun berubah. Padahal sebelum ini pemikiran keagamaan

Ahmad Khan bersifat puritan, sektarian dan apologetic. Sebaliknya setelah tahun 1857 , berubah menjadi rasional, 
dinamis dan prakmatis. Ia lebih konsen dengan nilai-nilai moral dan sosial daripada membicarakan masalah-masalah yang sulit dimengerti akal. Perubahan ini dapat dilihat pada sejumlah hasil karyanya setelah tahun 1857. Lebih jauh Siddiqui menambahkan, setelah 1857 dia menempatkan pemikiran keagamaan atas dasar risetnya yang kritis. Sekali waktu ia mengatakan, 'saya seorang muslim bukan karena saya dilabirkan di rumah Islam, tetapi saya percaya kepada Islam itu karena keyakinan dan hasil riset yang saya lakukan'.

Baginya sains dan tehnologi itu dapat memperkuat keyakinan agamanya apabila Islam berdasarkan dialektika tidak bertentangan dengan akal. Lebih lanjut Ahmad Khan menjelaskan bahwa makna Islam itu baru dapat dimengerti dengan baik oleh penganutnya apabila diwujudkan dalam praktek oleh pemeluknya. Oleh karena itu perjuangan Ahmad Khan tidak terbatas hanya memurnikan Islam tetapi lebih dari itu ia pun berjuang memurnikan keadaan komunitas muslim.

Sepenuhnya ia sadari bahwa mengadakan reformasi dalam bentuk sikap keberagamaan komunitas muslim India sangatlah sulit dan kompleksnya persoalan yang dihadapi. Ahmad Khan menyadari bahwa hal itu merupakan sebagian dari problema politik yang dihadapinya sejak tahun 1859, disamping penemuan baru yang harus diberi jawabannya oleh agama. Bashir Ahmad Dar menjelaskan sikap Ahmad Khan dalam persoalan ini. Tantangan Barat ini akan di antisipasi oleh Ahmad Khan dengan cara tetap mengadakan kerjasama dalam bidang politk, asimilasi kebudayaan dan mengadakan interpretasi ulang terhadap Idiologi Islam dalam bidang intelektual.

Guna merespon tantangan dari Barat, Ahmad Khan melancarkan reformasi dalam bidang moral, sosial dan akidah serta praktek-praktek keagamaan umat Islam secara kritis dan rasional. Dengan cara ini, ia percaya bahwa Islam akan efektif melayani kebutuhan masyarakat. Karena itu obsesi ini harus diwujudkan agar Islam sebagai satu-satunya agama yang paling benar di dunia ini dalam mengatur persoalan masyarakat dapat dibuktikan.

Pendekatan rasional yang dilakukan tokoh ini dalam memahami Islam tidaklah semata-mata karena adanya persentuhan dengan peradaban Barat tetapi dipengaruhi oleh 
Shekh Waliullah yang menekankan bahwa pemikiran Islam Itu harus dikaji ulang sehingga membuatnya sesuai dengan segala zaman.

Sumber ajaran Islam menurutnya hamyalah Al-Quran dan Hadis sedangkan ijtihad, ijma' dan qiyas tidak merupakan dasar Islam yang bersifat absolut. Demikian pula halnya Hadis, baru ia dapat diterima apabila setelah diteliti dengan sekasama tentang keasliannya karena masih banyak hadis palsu beredar ditengah masyarakat.

Sementara itu, Al-Quran baginya merupakan sumber yang paling dapat dipercaya dan sebagai dasar untuk memahami Islam. Dia berkeyakinan bahwa umat Islam sekarang sudah mampu menafsirkannya sesuai dengan kondisi sekarang dan tidak harus berpegang teguh pada penafsiran-penafsiran ulama terdahulu. Dengan kemajuan sains di abad 19, seorang muslim harus dapat memahami pesan-pesan AL-Quran itu baik secara kiasan maupun dalam bentuk tersurat. Oleh karenanya sebuah kajian serius tentang ilmu eksakta seperti yang dikembangkan di Barat memperkuat keyakinannya bahwa Al-Quran sebagai firman Allah dengan hukum alam sebagai ketetapan-Nya sudah pasti tidak terjadi pertentangan antara keduanya. Kepercayaannya yang kuat kepada Sunnatullah ini dikecam oleh ulama tradisionalis bahkan orang menuduhnya kafir.

Satu hal lain menarik untuk diamati, ialah keteguhan mayoritas ulama saat itu berpegang pada Ijma' ulama sebagai sumber hukum yang mengikat umat Islam saat ini. Ia beralasan bahwa perubahan zaman itu menjadikannya Ijma' masa lampau tidak berlaku, termasuk Ijma' para sahabat Nabi. Persoalan agama saat ini, menurutnya, harus diselesaikan oleh umat Islam sekarang yang lebih mengetahui problema kehidupannya. Untuk itu Ijtihad sangat penting kedudukannya. Ia menambahkan bahwa sarana Ijtihad itu akan dijadikan sebagai instrumen yang dapat merealisasikan kondisi objektif yang dihadapi agama. Ijtihad itu merupakan spirit dinamis dalam ajaran Islam dan dengan Ijtihad perseolan-persoalan baru dapat direspon oleh umat Islam yang sesuai dengan kondisi masa.

b. Reformasi bidang Pendidikan dan Sosial-Keagamaan

Kontribusi Ahmad Khan kepada Masyarakat Islam tidaklah terbatas dalam usahanya mengadakan perdamaian dengan penguasa Inggris. Dia telah memberikan sesuatu yang terbaik 
untuk kesejahteraan bangsanya, pendidikan modern. Ahmad Khan dipandang sebagai pelopor pendidikan modern bagi umat Islam India.

Dalam bidang intelektual, usahanya telah mampu menjembatani kesenjangan intelektual antara zaman pertengahan dan zaman modern. Karena itu sejak dini Ahmad Khan telah sadar akan pentingnya penggunaan bahasa Inggris sebagai media dalam pengajaran, dan peningkatan bahasa urdu di sisi lain lewat penerjemahan karya-karya dalam bidang ilmu sosial dan eksakta. Untuk menanggulangi hal ini ia mendirikan 'The Scientific Society' di Ghazifur tahun 1864.

Pada tahun 1869-70 Ahmad Khan mengunjungi Inggris dan berkesempatan mempelajari sistem pendidikan di universitas Cambrige. Kunjungan ini dimaksudkan untuk mempelajari cara pengolahan institusi tinggi bagi umat Islam. Pada 1874 ia telah merampungkan rencana pendirian "Mohammadan Anglo Oriental College" -MAOC—di Aligarh. Ahmad Khan bekerja keras untuk mewujudkan impiannya, akhirnya pada 1877 peletakan batu pertama College ini dilakukan oleh Lord Lytton, raja muda Inggris di India.

Lembaga ini dibentuk sesuai dengan model perguruan tinggi di Inggris dan bahasa Inggris menjadi bahasa pengantarnya. Disini ilmu pengetahuan modern merupakan mata kuliah pokok tanpa mengabaikan pendidikan agama. Bahkan ketaatan menjalankan ibadah sangat diperhatikan sekali. Sekolah ini terbuka untuk umum dan tidak eksklusif.

Dalam upayanya meningkatkan dan menyeragamkan standar mutu pendidikan secara nasional, di tahun 1886 diadakanlah konfrensi tentang pendidikan. Tujuan lembaga ini -Muhammedan Educational Conference- ialah menyebarluaskan pendidikan Barat dikalangan umat Islam, mengevaluasi pendidikan agama yang diberikan di sekolah-sekolah pemerintah dan yang dikelola oleh golongan Islam serta menunjang pendidikan agama yang diberikan di sekolah-sekolah swasta.

Ide-ide Ahmad Khan yang lain adalah penolakannya terhadap beberapa hukum Islam yang sudah tidak relevan lagi, seperti hukum potongan tangan bagi pencuri, perbudakan dan beberapa tradisi Islam seperti poligami. Tujuan utama dari doa adalah merasakan kehadiran Tuhan bukan untuk meminta sesuatu dari Tuhan. Dan melalui majalah Tahzi al-Akhlaq—majalah berbahasa 
Urdu - ia menyebarluaskan idei-denya yang informatif menyangkut persoalan-persoalan agama dan masyarakat. Selain itu ia juga berhasil menyusun Tafsir Alquran dalam tujuh jilid. Di dalamnya ia memberikan penjelasan-penjelasan rasional mengenai doktrindoktrin agama.

Sir Sayyid Ahmad Khan merupakan seorang figur pemikir Islam India terbesar yang mengisi kesenjangan intelektual abad pertengahan dan periode modern. Ia termasuk salah seorang tokoh pemimpin kebangkitan Islam abad ke- 19 di dunia Islam. Peranannya sangat vital terhadap kebangkitan kembali kaum Muslimin India dan dia memperkenalkan kepada mereka liberalisme Barat dan pemikiran-pemikiran bercorak rasional. Dua puluh tahun terakhir 1877-98 adalah masa yang paling indah baginya, karena impiannya mendirikan perguruan tinggi modern terwujud, sebuah karya monumental sebagai Bapak pendidik; sesuai dengan mottonya : didiklah! didiklah!

\section{Taha Husein dan Ide-Idenya di Mesir}

Taha Husein adalah seorang tokoh yang sangat kontroversial di dunia Islam, sastrawan besar yang pernah menjabat Mentri pendidikan Mesir ini dituduh penganjur sekularisme karena ia memang pernah menganjurkan saham total antara urusan keagamaan dan kedamaian.

Taha Husein telah tercatat namanya di dalam lembaran sejarah sebagai salah seorang pemikir pembaharuan di Mesir. Seperti para toko pembaharuan yang lainnya, ia juga melihat perlunya bangsa Mesir belaja dari Barat (Eropa) dan sekaligus mengambil kebudayaannya jika Mesir ingin maju dan kuat.

Sebagai sastrawan dan intelektual Muslim yang berpendidikan Barat, ia mencurahkan ide-ide pembaharuannya lewat karya tulis sastra dan ilmiahnya. Sebagian dari ide-ide tersebut berhasil ia wujudkan ketika ia menduduki jabatan yang penting di dalam pemerintahan.

Ide-ide Taha Husein pada mulanya dianggap kontroversial dan belum dapat diterima masyarakat Mesir kala itu, termasuk kaum terpelajarnya yang berpikiran tradisional. Bahkan Rasyid Ridla dan para ulama Azhar pada umumnya menganggap ide-ide yang dimunculkan Taha Husein telah membuat dirinya keluar dari Islam dan mempunyai efek negatif bagi mahasiswa Mesir. ${ }^{4}$ Akibatnya buku yang dianggap memuat ide-ide yang

\footnotetext{
${ }^{4}$ Harun Nasution, Pembaharuan dalam Islam; Sejarah Pemikiran dan Gerakan (Jakarta: Bulan Bintang, 1975), 86 dalam Mahmud Syafe'i, Perkembangan Modern Dunia Islam.
} 
menyimpang dan membahayakan umat Islam itu ditarik dari peredaran dan Taha Husein sendiri terpaksa diberhentikan dan dikeluarkan dari tempat ia mengajar di Universitas Cairo, bahkan ia juga akan diajukan ke pengadilan tetapi dibatalkan.

Ide-ide Taha Husein yang kontroversial itu dianggap sebagai ide sekularisasi (versi Barat) yang telah keluar dari Islam. Makalah ini mencoba memaparkan dan membahas apa dan bagaimana sesungguhnya ide-ide Taha Husein yang kontroversial tersebut. Untuk itu pembahasan akan diawali dengan pembatasan atau pengertian sekularisasi.

1. Ide-Ide Taha Husein

Ide-ide Taha Husein berkisar pada masalah pendidikan, meskipun secara khusus ia sangat memperhatikan bahasa, sastra, dan sejarah yang kesemuanya merupakan fenomena kebudayaan. Melalui pendidikan yang berorientasi pada kebudayaan Taha Husein ingin memajukan bangsa Mesir.

Namun perjalanan karirnya hampir selalu diwarnai kontrol krisis besar pertama dihadapinya pada tahun 1926, seolah terjadi ledakan bom, ketika bukunya yang berjudul On-Pre-Islamic Poetry terbit. tujuan buku itu melemparkan keraguan terhadap keautentikan al-qur'an dan hadits, juga terhadap ahli-ahli tafsir dan fikih yang terkenal pada masa lampau. ia menuduh bahwa syair-syair jahiliyah (pre-Islamic poetry) yang digunakan sebagai metode linguistic untuk menafsirkan al-qur'an adalah pemalsuan besar-besaran. karena itu para ulama' harus membuktikan apa yang telah mereka kemukakan.

Tuban telah menciptakan akal buat manusia yang cenderung ragu-ragu, bimbang dan ingin tahu. konsekuensi penting dari metode ini iaah amat penting tidak ada suatu yang lebih penting daripada revolusi intelektual. ${ }^{5}$

Kedua, melalui metode sastra yang dikuasainya, ia dianggap secara langsung dan tidak langsung menumbuhkan dasar-dasar Islam, salah satu bukti yang sering diangkat orang adalah argumentasinya dalam buku itu meragukan kebenaran ada tidaknya Nabi Ibrahim dan Nabi Isma'il secara historis, yakni berdasarkan kenyataan tidak adanya peninggalan sejarah, betapapun dalam al-Quran telah jelas menyebutkannya. ${ }^{6}$

a) Sastra Arab

\footnotetext{
${ }^{5}$ Dikutip dari Egypt in search of a political community, Nadav Safran, (Cambridge: Harvard University Press, 1961), 154 dalam Jamelah, Maryam and Margaret Marcus, Islam dan Modernisme, 194

${ }^{6}$ Jamelah, Maryam and Margaret Marcus, Islam dan Modernisme, 194
} 
Kontroversi ide Taha Husein muncul pertama kali pada tahun 1926 ketika diterbitkan bukunya Fi al-Adab al-Jahili' kajian kritis terhadap sastra Arab pra Islam dan sejarah umat-umat masa lampau yang berkembang di dunia Islam.

Dengan menggunakan metode-metode akademik kritis modern atau metode ilmiah untuk menganalisa syair-syair kuno Arab, Taha Husein sampai pada suatu kesimpulan bahwa sebagian besar dari syair-syair yang selama ini diyakini sebagai syair jahili perlu diragukan kebenaran dan keautentikannya. Hanya sebagian kecil saja dari syair-syair itu yang benar-benar ditulis pada masa pra Islam. Sedangkan sebagian besar lainnya ditulis pada masa pra Islam yang dihubung-hubungkan dengan para penyair terkenal untuk kepentingan memperkuat argumen-argumen yang diajukan para ahli tata bahasa, para teolog, ahli hadits dan ahli tafsir. ${ }^{7}$

Pendapat Taha Husein di atas ditentang keras oleh para ulama pada masa itu. Pendapat itu selain bertentangan dengan pendapat umum pada masa itu juga apabila metode kritis diterima dan digunakan untuk mengkaji teks-teks agama niscaya akan menimbulkan keragu-raguan terhadap keasliannya dan sekaligus akan menggusur dasar-dasar struktur tradisional pengajaran sastra Arab yang digunakan sebagai penguat kepercayaan beragama. Maka pada tahun 1932 Taha Husein dibebas tugaskan dari jabatannya sebagai Dekan Fakultas Sastra Universitas Kairo oleh rezim Sidqi Pash tetapi pada tahun 1936 ia dipulihkan kembali oleh rezim $\mathrm{Wafd}^{8}$.

b) Historiografi

Pendapat Taha Husein tentang sejarah sebagai ilmu pengetahuan pada waktu itu tidak kurang kontroversial dibanding pendapatnya tentang syair jahili di atas. Dalam bukuknya, 'Fi alAdab al-Jahili' ia menyatakan bahwa Taurat dan al-Quran berkisah tentang Ibrahim dan Ismacil, akan tetapi penyebutan nama-nama mereka di dalam Taurat dan al-Quran saja tidak cukup atau belum memadai untuk dijadikan bukti sejarah, biarkan sejarah sendiri yang akan menceritakan imigrasi Isma'il putera Ibrahim ke Mekah dan asal-usul bangsa Arab di sana. Kita cenderung melihat di dalam sejarah ini suatu bentuk fiksi untuk menetapkan

\footnotetext{
7 Tâhâ Husain, Fî al-Adab al-Jâhilî, (Beirut: Dar al-Kitab al-Lubnani, 1973), 67. Lihat juga Harun Nasution, dalam Mahmud Syafe'i, Perkembangan Modern Dunia Islam. ${ }^{8}$ Albert Hourani, 327 dalam Mahmud Syafe'i, Perkembangan Modern Dunia Islam.
} 
hubungan antara agama Islam di satu pihak dan Yahudi di lain pihak. $^{9}$

Taha Husein berusaha menerapkan metode studi kritis ala Perancis modern secara radikal terhadap kesusastraan Arab dengan sepenuh hati, Taha menerapkan metode-metode keragu-raguan falsafah (philosophic doubt) demikian jauh sehingga mencapai titik dimana opini di Mesir tidak siap menerimanya. Dituduhkan padanya bahwa jika metode kritik yang digunakannya diterapkan pada nash (al-Quran) dan hadits itu bisa menimbulkan akibat fatal, yakni keragu-raguan terhadap nash-nash itu sendiri. Sepintas lalu, dua pandangan pokok Taha Husein di atas seakan-akan menyiratkan sikap pelecehannya terhadap al-Quran dan tafsirantafsirannya selama ini melalui metode kritis modern yang ia terapkan dan karena itu pula ia dianggap menyebarkan ide sekularisasi, padahal kenyatannya tidak demikian. Taha sendiri membela diri dan mengatakan ia tidak sedikitpun berniat mengajak orang meragukan Islam. Menurutnya ia hanya ingin agar kita tidak bisa menerima begitu saja apa yang dikatakan orang-orang terdahulu kecuali setelah pengkajian dan pemastian.

Bagi Mesir untuk mengambil kebudayaan Barat itu mudah dilakukan karena Mesir pada hakekatnya merupakan bagian dari dunia Barat dalam artian kultural dan bukan geografik. Karena peradabannya didasarkan atas falsafah Yunani dan system hukum Romawi, maka Mesir tidak termasuk peradaban Timur seperti Cina dan India. Lebih dari itu, Mesir yang Muslim pun dapat mengadopsi kebudayaan Barat Modern yang sekuler dengan mudah sebagaimana Islam telah mengasimilasi kebudayaa Yunani dan Persia dengan mudah pada masa lalu. Dengan mengambil peradaban Barat tanpa agamanya umat Islam akan dapat menuju kemajuan dan kehidupan modern. ${ }^{10}$

Adapun kenyataan bahwa Mesir yang merupakan bagian dari Bara tertinggal dan lebih mundur dibandingkan dengan Negaranegara lainnya di Eropa karena penjajahan Turki yang membawa pada penghancuran peradaban. Peradaban-peradaban antara Mesir dan Eropa bersumber pada satu kenyataan bahwa renaissance di

\footnotetext{
${ }^{9}$ S. Kurayyin, Ma'arik Taha Husein al-Adabiah wa al-Fikriah (Beirut: Dar al-Qalam, 1977), 4 dalam Syafe'i, Mahmud, Perkembangan Modern Dunia Islam.

10 C.C. Adam, Islam and Modernism in Egypt, (London: Oxford University Press, 1933), 258 dalam Mahmud Syafe'i, Perkembangan Modern Dunia Islam.
} 
Eropa terjadi pada abad ke-15 sedangkan di Mesir baru terjadi pada abad ke-19.

c) Negara

Taha Husein menganut faham nasionalisme Mesir. Ia berpendapat bahwa di dunia modern, pusat loyalitas dan kesatuan sosial adalah Negara, dan baginya Negara itu berarti Mesir. Kesatuan wilayah baginya merupakan pokok dari solidaritas sosial dan perasaan kenegaraannya tertuju pada tanah air, dan bukan pada kebangsaan ia pun tidak membedakan antara warga Negara Muslim Mesir dan non Muslim. Sentiment nasional baginya paling penting. Dalam analisis terakhir yakin bahwa individu dan hak-haknya adalah lebih tinggi dari pada Negara; tetapi diantara masyarakatmasyarakat Negara adalah yang paling tinggi.

Dalam kesatuan Nasional itu ia melihat agama penting dilihat dari nilai sosialnya yang merupakan isi dari ide nasional serta memperkokoh kesatuan Negara. Isalam adalah salah satu faktor di dalam nasionalisme Mesir, ${ }^{11}$ karena itu di sekolah-sekolah harus diajarkan agama nasional sebagaimana sejarah nasional diajarkan. Betapa pentingnya agama, tetapi ia tidak dapat dijadikan pemandu dalam kehidupan politik atau sebagai batu ujian dari politik nasional, ide Negara harus didefinisikan di luar istilah-istilah religius.

Tentang bahasa Arab Taha Husein tidak menekankan pada kepentingannya sebagai sarana kebangkitan agama, tetapi sebagai basis dari kehidupan nasional. Ia menganggap kepentingan bahasa Arab bukan bahasa bagi Muslim saja, tetapi ia bahasa semua yang berbicara bahasa Arab betapapun berbeda keyakinan mereka. ${ }^{12}$ Karena pentingnya bahasa Arab dan agama Islam di dalam membentuk nasionalisme Mesir keduanya wajib diajarkan di semua sekolah Mesir.

d) Pendidikan

Sesuai dengan profesinya sebagai pendidik, Taha Husein mengamati perlunya reformasi sistem pendidikan (sekolah) di Mesir. Tujuan pertama pendidikan adalah peradaban dan ilmu pengetahuan (sains) yang merupakan bagian vital dalam pengajaran kebijakan-kebijakan berwarga negara serta menciptakan kondisi yang kondusif untuk suatu pemerintahan yang demokratis.

${ }^{11}$ C.C. Adam, Islam, 333

${ }^{12}$ C.C. Adam, Islam, 334.

101 Zainur Arifin - Politik Pendidikan Islam Masa Modern 
Pendidikan dasar sebagai dasar kehidupan yang demokratis harus bersifat universal (umum) dan diwajibkan. Pendidikan menengah memiliki problem yang lebih sukar karena ada beberapa macam pendidikan; keagamaan, asing, dan negeri. Dalam hal ini pemerintah harus mengadakan kontrol. Sekolah asing wajib mengajarkan bahasa nasional (Arab), sejarah, geografi, dan agama nasional (Islam); dalam hal ini sekolah misionaris Kristen diharuskan mengajarkan agama Islam pada muridnya yang Muslim. Sekolah-sekolah agama tingkat dasar dan menengah yang menginduk pada Azhar harus di bawah pengawasan pemerintah. Sedang untuk sekolah negeri harus dilakuikan tiga perubahan penting: Pertama sekolah-sekolah harus diperbanyak sesegera mungkin; kedua pendidikan menengah harus tersedia bagi siapa saja yang sanggup membayar dan bagi murid yang miskin tetapi pintar digratiskan; ketiga harus dirubah kandungan materi pendidikannya.

Tentang materi yang harus dirubah terutama pengajaran bahasa, menyangkut metodologi dan macam bahasa asing yang diajarkan. Ia menganjurkan agar bahasa asing tidak diajarkan sebelum usia lima tahun, tetapi setelah itu harus diajarkan dengan intensif. Ada beberapa bahasa asing pilihan yaitu bahasa Inggris, Prancis, Jerman, dan Itali; namun bahasa klasik pun juga harus ada seperti bahasa Yunani, Latin, Ibrani, dan Persia.

Untuk pendidikan tinggi ia tidak banyak memberi saran. Dalam pandangannya perguruan tinggi adalah independen, ia tidak boleh dikendalikan dan diarahkan oleh pemerintah. Tegasnya universitas harus mempunyai kebebasan yang absolute. Konsepsi pendidikan Taha Husein untuk segala tingkatan bersifat humanis, universitas yang pokok dan utama harus merupakan masyarakat intelektual yang didasari cinta kasih dan persahabatan serta kebersamaan dan solideritas. ${ }^{13}$

Sebagai salah satu pusat pendidikan tinggi, Al-Azhar juga harus memiliki kebebasan yang sama dengan universitas-universitas lainnya. Ia memainkan peranan penting di dalam membentuk peradaban nasional Mesir karena banyaknya mahasiswa, hubungannya yang erat dengan segala golongan masyarakat serta tradisinya sendiri. Namun fungsinya sangat khusus, sebagai pusat studi keagamaan dan sumber kehidupan spiritual bagi negara. Al-

${ }^{13}$ C.C. Adam, Islam, 337. 
Azhar juga dituntut untuk mengajarkan Islam yang sebenarnya sebagai agama kebebasan, sains dan pengetahuan, perkembangan, kemajuan, dan menghargai kehidupan spiritual dan material secara seimbang; ia juga dituntut untuk menanamkan patriotisme territorial dan bukan ide lama tentang nasionalisme religus.

Sebagai penasehat Kementrian Pendidikan (1024-1944), ia berperan besar di dalam pendirian Universitas Alexandria dan menjadi rektor pertamanya sehingga lebih leluasa untuk mengetrapkan idenya di perguruan tinggi. Sebagai Menteri Pendidikan (1950-1952) ia pun lebih leluasa lagi untuk mengambil kebijaksanaan pendidikan sesuai dengan idenya. Dalam tempo singkat ia berhasil mengembangkan jumlah sekolah negeri pada seluruh tingkatan. Muncullah universitas-universitas baru, sekolahsekolah tinggi, dan sekolah-sekolah baru setiap macam. Ia pun berhasil membebaskan biaya pendidikan untuk tingkat menengah serta merevisi kurikulum. Terlepas dari segenap kontroversi yang menyelimuti dirinya, M. Taha Husain telah terukir sebagai salah seorang tokoh penting dalam perkembangan modern, maupun dalam modernisasi dalam pengertian yang luas, di Mesir. Sampai dengan prestasinya yang senantiasa dikenang orang adalah ketika tahun 1950 lembaga pendidikan bebas bagi setiap anak mesir.

Taha Husein yang kaya ide dan banyak karya nyatanya dalam bidang sastra dan pendidikan pantas mendapat predikat salah seorang pembaharu di Mesir khususnya dan di dunia Islam pada umumnya. Ide-idenya yang imaginative dan ilmiah akademik, pada mulanya dianggap sebagai kontroversial dan dikecam dengan keras, tetapi pada masa selanjutnya diterima bahkan sebagian berhasil ia realisasian berkat kewenangannya.

Pendapat-pendapat humanisnya nampak serupa dengan ide sekularisasi di Barat tetapi tidak sama karena sebagai muslim ia tidak pernah bermaksud melepaskan diri dari agama, sekularisasinya lebih dipahami sebagai melepaskan diri dari pemahaman tradisional yang tidak ilmiah. Nilai penting pandangan-pandangan Thaha Husain bukanlah terutama terletak pada substansinya melainkan pada sikap ilmiah, dan pendekatannya yang modern dalam bentuk penerapan suatu materi berpikir. 


\section{Daftar Pustaka}

Adam, C.C. Islam and Modernism in Egypt. Londom: Oxford University Press, t.th.

Nasution, Harun. Pembaharuan dalam Islam; Sejarah Pemikiran dan Gerakan. Jakarta: Bulan Bintang, 1975

Kurayyin, S. Ma ârik Țahâ Husain al-Adâbiah wa al-Fikeriah. Beirut: Dar alQalam, 1977.

Syafe'i, Mahmud. Perkembangan Modern Dunia Islam. t.tp.: CV. Vasindo dan Value Press Bandang, 2008.

Starrett. dalam Robert W Hefner n Qasim Zaman. Schooling Muslim. 1998.

Husain, Țâhâ. Fî al-Adab al-Jabilî. Beirut: Dar al-Kitab al-Lubnani, t.th. 